\title{
Expression and epigenetic regulatory mechanism of BNIP3 in clear cell renal cell carcinoma
}

\author{
YANXIANG SHAO $^{1 *}$, ZHENHUA LIU $^{1 *}$, JIANBANG LIU $^{1}$, HAIZHOU WANG $^{1}$, LONG HUANG $^{1}$, \\ TIANHAI LIN ${ }^{1}$, JIYAN LIU ${ }^{2}$, QIANG WEI ${ }^{1}$, HAO ZENG $^{1}, \mathrm{GU} \mathrm{HE}^{3}$ and XIANG LI ${ }^{1}$ \\ ${ }^{1}$ Department of Urology, Institute of Urology; ${ }^{2}$ Department of Oncology; ${ }^{3}$ State Key Laboratory of Biotherapy, \\ West China Hospital, West China Medical School, Sichuan University, Chengdu, Sichuan 610041, P.R. China
}

Received April 2, 2018; Accepted October 2, 2018

DOI: $10.3892 /$ ijo.2018.4603

\begin{abstract}
The majority of clear cell renal cell carcinomas (ccRCCs) are caused by an accumulation of hypoxia-inducible factor (HIF) and the overexpression of downstream genes in response to the von Hippel-Lindau (VHL) gene becoming inactivated. In the present study, our hypothesis was that $B N I P 3$, a gene positioned downstream of HIF, would be expressed at a higher level in ccRCC; however, instead, lower levels of BNIP3 expression were identified in RCC tumor tissues compared with adjacent non-tumor tissues. These changes were associated with lower levels of VHL, and higher levels of HIF and vascular endothelial growth factor. BNIP3 was also undetectable in three investigated RCC cell lines (786-O, ACHN, A498) and GRC-1-1 cells. Methylation of the $B N I P 3$ promoter was not detected, and neither did treatment with a methylation inhibitor cause cell proliferation. However, treatment with a histone deacetylation inhibitor, trichostatin A (TSA), inhibited cultured RCC cell proliferation, promoted apoptosis and restored BNIP3 expression. Furthermore, histone deacetylation of the BNIP3 promoter was identified in ACHN and 786-O cells, and the acetylation status was restored following TSA treatment. Taken together, the results of the present study suggest that histone deacetylation, but not methylation, is most likely to cause BNIP3 inactivation in RCC. The data also indicated that restoration of BNIP3 expression by a histone deacetylation inhibitor led to growth inhibition and apoptotic promotion in RCC.
\end{abstract}

Correspondence to: Professor Xiang $\mathrm{Li}$, Department of Urology, Institute of Urology, West China Hospital, West China Medical School, Sichuan University, 37 GuoXueXiang, Chengdu, Sichuan 610041, P.R. China

E-mail: xiangli.87@163.com

*Contributed equally

Key words: carcinoma, renal cell, hypoxia-inducible factor, Bcl-2/adenovirus E1B $19 \mathrm{kDa}$ interacting protein 3, BNIP3, DNA methylation, histone deacetylation, epigenetic regulation

\section{Introduction}

As the most commonly occurring urological neoplasms, renal cell carcinomas (RCCs) are almost always detected at middle or advanced stages. Even among localized RCCs that are usually defined as early-stage disease, $20-30 \%$ of cases metastasize within 1-2 years following surgery (1). Nephrectomy alone is ineffective as a treatment, and systemic therapy is therefore imperative for these advanced and metastatic RCCs. In-depth investigation of the von Hippel-Lindau (VHL)/hypoxia-inducible factor (HIF) hypoxia-response pathway in RCC has led to significant progress in identifying potential molecular drug targets (2). For example, patients with advanced RCC are known to benefit much more from sunitinib treatment compared with interferon- $\alpha$ therapy in terms of survival and disease control (3). Although targeted therapy has now become the standard treatment for advanced RCC, there are clear limitations to this practice, particularly its low disease control objective response rate. In addition, the mechanisms regulating RCC growth remain unclear. Consequently, there is an urgent need to investigate the mechanisms underlying tumor growth and to identify novel treatment targets.

Approximately $70-80 \%$ of RCC cases involve clear cell RCC (ccRCC) (4). Mutations or heterozygous deletions of the tumor suppressor gene, $V H L$, are known to occur in the majority of ccRCCs, leading to reduced expression of VHL protein (pVHL). pVHL is able to specifically bind to HIF and induce its ubiquitination under physiological conditions, and also under hypoxic conditions; low expression levels of $V H L$ can also lead to HIF accumulation $(2,5)$. HIF is a nuclear transcription factor with a crucial regulatory function in activation of downstream hypoxia-responsive genes via promoter regions containing hypoxic response elements (HREs). Hence, HIF accumulation activates downstream genes, including vascular endothelial growth factor $(V E G F)$, transforming growth factor- $\alpha$ and platelet-derived growth factor, which have important roles in tumor growth and progression $(2,6)$.

Bcl-2/adenovirus E1B $19 \mathrm{kDa}$ interacting protein 3 (BNIP3) is a mitochondrial proapoptotic protein, and an important apoptotic regulator that belongs to the B-cell lymphoma 2 (Bcl-2) protein family (7). As the only members of the Bcl-2 family with promoters containing HREs, BNIP3 and BNIP3-like protein (BNIP3L) may be activated by HIF 
under hypoxic conditions, and subsequently contribute to hypoxia-induced cell death via mechanisms including apoptosis, necrosis and autophagy (8).

The majority of RCCs are solid tumors in which hypoxic-ischemic areas inevitably develop (9-12), potentially leading to HIF accumulation. In addition, as VHL inactivation occurs in the majority of ccRCCs, even without hypoxic stimulation, HIF may still accumulate abnormally. As a gene downstream of HIF, BNIP3 was originally anticipated to be activated in RCC; however, a recent study demonstrated low levels of BNIP3 expression in ccRCC, inconsistent with the high levels of HIF observed in these cancers, suggesting that a different mechanism may inhibit the expression of BNIP3 in this context (13).

Only a limited number of studies have been performed to assess the role of BNIP3 in RCC, and the mechanisms underlying its downregulation in these tumors have yet to be elucidated. In the present study, the expression of BNIP3 in RCC tissue samples and cell lines was investigated. The methylation and histone deacetylation status of BNIP3 in RCC was also examined, and the levels of cell proliferation and apoptosis following treatment with methylation or histone deacetylase inhibitors were investigated in order to clarify the function of BNIP3 in RCC, and to investigate its potential as a novel treatment target for RCC.

\section{Materials and methods}

Tissue samples and clinical data. Samples from 30 patients, diagnosed pathologically with ccRCC between September 2012 and March 2013, and adjacent non-tumor samples, were provided by the Department of Urology of West China Hospital (Chengdu, China). Samples were used according to ethical guidelines and procedures approved by the West China Hospital of Sichuan University Biomedical Research Ethics Committee. After examination by a pathologist, tissue samples were preserved immediately in liquid nitrogen. The present study comprised 19 males and 11 females, aged 47-71 years of age (with 8 cases $>65$ years of age); all patients were untreated prior to surgery. According to the staging system of the American Joint Committee on Cancer, 5, 14, 7, and 4 tumors were stage I, II, III, and IV, respectively.

Cell lines and general reagents. The human ccRCC cell line, 786-O, the human RCC cell lines, ACHN, A498, and GRC-1, the normal human renal tubular epithelial cell line, HK-2, the human prostate cancer cell lines, PC3 and Du145, and the human colorectal cancer cell line, SW480, were obtained from the Laboratory of Pathology, West China Medical School, Sichuan University (Chengdu, China). Following cell dissociation and propagation, the 786-O, A498, ACHN, and GRC-1-1 cell lines were cultured $\left(37^{\circ} \mathrm{C}\right)$ and grown in Roswell Park Memorial Institute (RPMI) medium using 1640 complete medium (Gibco ${ }^{\circledR}$; Thermo Fisher Scientific, Inc., Waltham, MA, USA). The GRC-1 RCC line was established at the Institute of Urology, Peking University (Beijing, China), was first reported by Ding et al (14), and has been subsequently used in numerous studies $(15,16)$. PC3 and Du145 cells were cultured $\left(37^{\circ} \mathrm{C}\right)$ in Dulbecco's modified Eagle's medium (DMEM) complete medium $\left(\mathrm{Gibco}^{\circledR}\right.$; Thermo Fisher
Scientific, Inc.), whereas $\mathrm{HK}-2$ cells were cultured $\left(37^{\circ} \mathrm{C}\right)$ in F-12 Complete ${ }^{\mathrm{TM}}$ medium (Gibco ${ }^{\circledR}$; Thermo Fisher Scientific, Inc.) in microcentrifuge tubes (Eppendorf, Stevenage, UK) in a humidified incubator in an atmosphere of $5 \% \mathrm{CO}_{2}$ and $95 \%$ air.

Primer synthesis. Mature mRNA sequences were acquired from the GenBank sequence database (http://www.ncbi.nlm. nih.gov/genbank). Polymerase chain reaction (PCR) primers for tissue samples and culture cells were subsequently designed using Primer5 software. The primers for methylation-specific PCR of BNIP3 were identical with those used by Okami et al (17) and Bacon et al (18). The primers used in chromatin immunoprecipitation (ChIP) assays were designed by Shanghai Invitrogen Biotechnology Co., Ltd. (a subsidiary of Life Technologies Corporation; Shanghai, China), with the forward primer running from position 131,982,902 to position $131,982,882$ of the BNIP3 template, and the reverse primer running from position $131,982,354$ to position $131,982,373$. All primers were synthesized by Shanghai Invitrogen Biotechnology Co., Ltd.

Reverse transcription (RT)-PCR. Total RNA was extracted from preserved tissue samples or cultured cells using RNAiso Plus reagent (Takara Biotechnology Co., Ltd., Dalian, China) or TRIzol reagent (Thermo Fisher Scientific, Inc.). Purified RNA was then quantified and assessed for purity using ultraviolet (UV) spectrophotometry. RT was performed with reaction mixtures (made up to a total volume of $20 \mu \mathrm{l}$ ) as described in Table I. The PCR primers used for the detection of BNIP3 were as follows: Forward, 5'-CAGGGCTCCTGG GTAGAACT-3' and reverse, 5'-CTACTCCGTCCAGACTCA TGC-3' (131 bp). PCR reactions were performed according to the protocol described in Table II. PCR products were loaded onto $2 \%$ agarose gels and visualized with ethidium bromide under UV light. As a control for cDNA synthesis, RT-PCR was also performed using primers specific for the GAPDH gene.

RT-quantitative PCR (RT-qPCR). RT-qPCR was performed using a PTC-200 Peltier Thermal Cycler instrument (MJ Research, Ramsey, MN, USA) according to the manufacturer's protocol described in Table III. The sequences of the PCR primers used for detecting BNIP3 were as follows: $V H L$, forward primer, 5'-GGAGCCTAGTCAAGCCTGAGA-3'; reverse, 5'-CATCCGTTGATGTGCAATGCG-3' (134 bp); HIF-1 $\alpha$, forward primer, 5'-ATCCATGTGACCATGAGG AAATG-3'; reverse, 5'-TCGGCTAGTTAGGGTACACTTC-3' (125 bp); VEGF, forward primer, 5'-AGGGCAGAATCATCA CGAAGT-3'; reverse, 5'-AGGGTCTCGATTGGATGGCA-3' (75 bp); GAPDH, forward primer, 5'-GTCTTCACCACCATG GAGAA-3'; reverse, 5'-ATCCACAGTCTTCTGGGTGG-3' (268 bp). The GAPDH gene was used as a positive control. The PCR conditions were as follows: One cycle of denaturation at $95^{\circ} \mathrm{C}$ for $2 \mathrm{~min}$, followed by 39 cycles of $95^{\circ} \mathrm{C}$ for $20 \mathrm{sec}, 60^{\circ} \mathrm{C}$ for $30 \mathrm{sec}$, and $72^{\circ} \mathrm{C}$ for $30 \mathrm{sec}$. The copy number of target genes (relative to $G A P D H$ ) from the tissue samples was determined using the $2^{-\Delta \Delta \mathrm{Cq}}$ method (19), with $\Delta \Delta \mathrm{Cq}=\Delta \mathrm{Cq}_{\text {tumor }}$ tissues(T) $-\Delta \mathrm{Cq}_{\text {adjacent non-tumor tissues }(\mathrm{N})}=\left(\mathrm{Cq}_{\mathrm{T} \text {-target }}-\mathrm{Cq}_{\mathrm{T}-G A P D H}\right)-\left(\mathrm{Cq}_{\mathrm{N} \text {-target }}{ }^{-}\right.$ $\left.\mathrm{Cq}_{\mathrm{N}-G A P D H}\right)$, whereas the copy number for cultured cells was determined by the $\Delta \mathrm{Cq}$ method, with $\Delta \mathrm{Cq}=\mathrm{Cq}_{G A P D H}-\mathrm{Cq}_{\text {gene }}$. 
Table I. Details of the reverse transcription reaction mixtures.

\begin{tabular}{|c|c|c|c|}
\hline \multirow[b]{2}{*}{ Reagent } & \multicolumn{3}{|c|}{ Amount } \\
\hline & Tissue samples & RCC cell lines & Cells treated with TSA \\
\hline Total RNA & $5 \mu \mathrm{g}$ & $2 \mu \mathrm{g}$ & $2 \mu \mathrm{g}$ \\
\hline 5X RT buffer & $4 \mu 1$ & $4 \mu 1$ & $4 \mu 1$ \\
\hline dNTPs (10 mM) & $2 \mu 1$ & $2 \mu 1$ & $2 \mu 1$ \\
\hline DTT (0.1 M) & $1 \mu 1$ & $1 \mu 1$ & $1 \mu 1$ \\
\hline Oligo (dT) 18 & $1 \mu 1$ & $1 \mu 1$ & $1 \mu 1$ \\
\hline ReverTra Ace ${ }^{\circledR}$ & $0.8 \mu 1$ & $1 \mu 1$ & $1 \mu 1$ \\
\hline $\mathrm{DEPC} \mathrm{ddH}_{2} \mathrm{O}$ & Up to total volume of $20 \mu 1$ & Up to total volume of $20 \mu 1$ & Up to total volume of $20 \mu 1$ \\
\hline
\end{tabular}

Table II. Details of the PCR mixtures for cell lines and methylation-specific PCR.

\begin{tabular}{lc} 
A, Cultured cell lines & \\
\hline Reagent & Amount $(\mu \mathrm{l})$ \\
\hline Taq DNA polymerase & 0.25 \\
10X PCR buffer & 2.5 \\
$25 \mathrm{mmol} / \mathrm{l} \mathrm{MgCl}$ & \\
$10 \mathrm{mmol} / \mathrm{l} \mathrm{dNTP}$ & 1.5 \\
Upstream primer $(100 \mu \mathrm{M})$ & 0.5 \\
Downstream primer $(100 \mu \mathrm{M})$ & 0.1 \\
cDNA & 0.1 \\
ddH ${ }_{2} \mathrm{O}$ & 1 \\
\hline
\end{tabular}

B, Methylation-specific PCR

\begin{tabular}{lc}
\hline Reagent & Amount $(\mu \mathrm{l})$ \\
\hline Takara Taq HS $(5 \mathrm{U} / \mu \mathrm{l})$ & 0.1 \\
10X HS buffer $\left(\mathrm{Mg}^{2+}\right.$ plus $)$ & 2 \\
$2.5 \mathrm{mmol} / \mathrm{l}$ dNTP & 1.6 \\
Upstream primer $(100 \mu \mathrm{M})$ & 0.1 \\
Downstream primer $(100 \mu \mathrm{M})$ & 0.1 \\
cDNA & 3 \\
ddH $\mathrm{H}_{2} \mathrm{O}$ & $\mathrm{Up}$ to 20 \\
\hline
\end{tabular}

The specific reagents were purchased from the following sources: Taq DNA polymerase (Tiangen Biotech Co., Ltd., Beijing, China); Takara Taq HS (Takara Biotechnology Co., Ltd., Dalian, China); PCR, polymerase chain reaction; $\mathrm{ddH}_{2} \mathrm{O}$, doubly distilled $\mathrm{H}_{2} \mathrm{O}$.

Western blotting. Total cell protein was collected from cells following lysis in buffer (Roche Diagnostics $\mathrm{GmbH}$, Mannheim, Germany) containing leupeptin, pepstatin A,
Table III. Details of the reaction mixtures for reverse transcription-quantitative polymerase chain reaction.

\begin{tabular}{lc} 
Reagent & Amount $(\mu \mathrm{l})$ \\
\hline 2X SYBR-Green real-time PCR mix & 10 \\
Upstream primer $(10 \mu \mathrm{M})$ & 0.4 \\
Downstream primer $(10 \mu \mathrm{M})$ & 0.4 \\
cDNA & 2.0 \\
ddH $_{2} \mathrm{O}$ & 7.2 \\
Total volume & 20 \\
\hline
\end{tabular}

SYBR-Green real-time PCR mix was purchased from Takara Biotechnology Co., Ltd. (Dalian, China). $\mathrm{ddH}_{2} \mathrm{O}$, doubly distilled $\mathrm{H}_{2} \mathrm{O}$.

aprotinin and phenylmethanesulfonyl fluoride (PMSF). The protein concentration was measured using the bicinchoninic acid (BCA) protein assay reagent kit (Beyotime Institute of Biotechnology, Haimen, China). After mixing with SDS loading buffer (Calbiochem; now a subsidiary of EMD/Merck Millipore, Billerica, MA, USA) and boiling for $5 \mathrm{~min}$, the protein samples were separated by SDS/PAGE gels (12\%) and transferred on to a polyvinylidene difluoride (PVDF) membrane (GE Healthcare Life Sciences, Little Chalfont, UK). Membranes were subsequently blocked with $15 \%$ fat-free milk powder (for BNIP3) or 5\% fat-free milk powder (for VHL, HIF-1 $\alpha$, VEGF and GAPDH), and separated in Tris-buffered saline containing $0.1 \%$ Tween-20 (TBST) buffer for $90 \mathrm{~min}$ at room temperature. Corresponding membranes were then incubated with primary antibodies against BNIP3 (cat. no. B7931, 1:3,000; Sigma-Aldrich; now a brand of Merck, KGaA, Darmstadt, Germany), VHL (cat. no. 68547, 1:1,000; CST Biological Reagents Co., Ltd., Shanghai, China), HIF-1 $\alpha$ (cat. no. 610959, 1:2,000; BD Biosciences, San Jose, CA, USA), VEGF (cat. no. BA0407, 1:100; Boster Biological Technology, Pleasanton, CA, USA), and GAPDH (cat. no. KC-5G4, 
1:10,000; Kangchen BioTech Co., Ltd., Shanghai, China) at $4^{\circ} \mathrm{C}$ overnight. After washing in TBST buffer, the membranes were subsequently incubated with horseradish peroxidase (HRP)-conjugated goat anti-mouse or rabbit IgG secondary antibodies (cat. nos. 31430 for mouse and 31460 for rabbit, respectively; 1:5,000; Zymed ${ }^{\circledR}$; Thermo Fisher Scientific, Inc.) at room temperature for $1 \mathrm{~h}$. After further TBST washing, the antigen-antibody reaction was visualized using the enhanced chemiluminescence (ECL) assay (Roche Diagnostics GmbH), and the blots were analyzed using a DP70 digital camera (Olympus Corporation, Tokyo, Japan). The intensity (gray value) of each protein sample was calculated and normalized to the internal control, GAPDH.

Genomic DNA isolation, methylation modification, and methylation-specific (MS)-PCR. Genomic DNA was isolated from tissue samples and cultured cells using a Promega DNA purification kit (Promega Corporation, Madison, WI, USA), in accordance with the manufacturer's protocol. After the purity and concentration of DNA was quantified and assessed, methylated residues were modified using a ZYMO DNA Methylation-Gold kit (Zymo Research Corp., Irvine, CA, USA) to differentiate methylated $\mathrm{CpG}$ from unmethylated CpGs. Using this treatment, unmethylated cytosines were converted into uracil, whereas methylated cytosine remains as cytosine. Subsequently, MS-PCR was performed using the reaction mixtures described in Table II. The PCR conditions were as follows: One cycle of denaturation at $95^{\circ} \mathrm{C}$ for $5 \mathrm{~min}$, followed by 35 cycles of $95^{\circ} \mathrm{C}$ for $30 \mathrm{sec}, 64$ or $58^{\circ} \mathrm{C}$ (methylated or unmethylated) for $50 \mathrm{sec}$, and $72^{\circ} \mathrm{C}$ for $30 \mathrm{sec}$. Primer sequences for the unmethylated reaction were as follows: Forward, 5'-TAGGATTTGTTTTGTGTATG-3', and reverse, 5'-ACCACATCACCCATTAACCACA-3' (94 bp), whereas for the methylated reaction, the following primers were used: Forward, 5'-TAGGATTCGTTTCGCGTACG-3', and reverse, 5'-ACCGCGTCGCCCATTAACCGCG-3' (94 bp).

Assessment of cell proliferation following treatment with 5-aza-cytidine (5-aza-C) or TSA. Cells collected from cell culture flasks were grown on 96-well plates (Corning Incorporated, Corning, NY, USA) at a concentration of $5 \times 10^{3}$ cells per well, and then incubated with in atmosphere of $5 \% \mathrm{CO}_{2}$ and $95 \%$ air. After $24 \mathrm{~h}$ of incubation, the culture medium was substituted with medium containing $2 \%$ fetal calf serum and $5 \mu \mathrm{M} 5$-aza-C (Merck, KGaA) or $1.5 \mu \mathrm{M}$ of the histone deacetylase inhibitor (HDACI), TSA (Merck, KGaA), which was renewed every $12 \mathrm{~h}$ for $72 \mathrm{~h}$. Following treatment, $10 \mu \mathrm{l}$ cholecystokinin octapeptide (CCK-8) (Dojindo Molecular Technologies, Inc., Kumamoto, Japan) was added to each tube, followed by incubation for $4 \mathrm{~h}$. Finally, in order to determine the levels of cell proliferation, absorbance at $450 \mathrm{~nm}$ was measured using a microplate reader (Bio-Rad Laboratories, Inc., Hercules, CA, USA).

Evaluation of proliferation and apoptosis following treatment with different concentrations of TSA. Cultured cells (786-O, ACHN, and A498) used to evaluate proliferation were grown on 96-well plates at a concentration of $3 \times 10^{3}$ cells per well, whereas cells for apoptotic evaluation were grown on 6-well plates (Corning Incorporated) at a concentration
Table IV. PCR reaction details for TSA treated cells and ChIP.

A, Cells treated with TSA

\begin{tabular}{lc}
\hline Reagent & Amount $(\mu \mathrm{l})$ \\
\hline Taq DNA polymerase & 0.25 \\
10X PCR buffer & 2.5 \\
$25 \mathrm{mmol} / \mathrm{l} \mathrm{MgCl}$ & \\
$10 \mathrm{mmol} / \mathrm{l}$ dNTP & 1.5 \\
Upstream primer $(10 \mu \mathrm{M})$ & 0.5 \\
Downstream primer $(10 \mu \mathrm{M})$ & 0.1 \\
cDNA & 0.1 \\
dd ${ }_{2} \mathrm{O}$ & 1 \\
\hline
\end{tabular}

\section{B, ChIP}

Reagent

Amount $(\mu 1)$

Taq DNA polymerase

10X PCR buffer

12.5

$25 \mathrm{mmol} / \mathrm{l} \mathrm{MgCl}_{2}$

$10 \mathrm{mmol} / \mathrm{l} \mathrm{dNTP}$

$-$

Upstream primer $(10 \mu \mathrm{M})$

Downstream primer $(10 \mu \mathrm{M})$

0.1

cDNA

0.1

1

$\mathrm{ddH}_{2} \mathrm{O}$

Up to 25

Taq DNA polymerase was purchased from Tiangen Biotech Co., Ltd. (Beijing, China). PCR, polymerase chain reaction; $\mathrm{ddH}_{2} \mathrm{O}$, doubly distilled $\mathrm{H}_{2} \mathrm{O}$; ChIP, chromatin immunoprecipitation; TSA, trichostatin A.

of $1.2 \times 10^{6}$ cells per well. Subsequently, cells were incubated in an atmosphere of $5 \% \mathrm{CO}_{2}$ and $95 \%$ air for $24 \mathrm{~h}$ prior to renewing the media containing $0.5,1.0$, or $2.0 \mu \mathrm{mol} / 1 \mathrm{TSA}$, as appropriate. Cells treated with medium without TSA were used as a negative control, whereas medium without the cells was used as a blank control. The cell medium was renewed every $24 \mathrm{~h}$ for all groups. The proliferation of cells was evaluated at $0,24,48$, and $72 \mathrm{~h}$ using CCK-8, as described above. Apoptosis was examined at $48 \mathrm{~h}$ using Annexin V-fluorescein isothiocyanate (FITC) (Dojindo Molecular Technologies, Inc.,) and flow cytometry (Instrument: Bio-Rad Laboratories, Inc; Software: NoveExpress ${ }^{\mathrm{TM}}$ ), in accordance with the manufacturer's protocol.

Evaluation of gene expression following TSA treatment. Total RNA was extracted from cultured cells treated with different concentrations of TSA for $24 \mathrm{~h}$ as described above, with cells grown in medium without TSA being used as a negative control. RT-PCR was performed with the reaction mixtures described in Table I, whereas PCR was performed with the reaction mixtures described in Table IV. The PCR conditions were as follows: One cycle of denaturation at $95^{\circ} \mathrm{C}$ for $1 \mathrm{~min}$, followed by 35 cycles of $95^{\circ} \mathrm{C}$ for $10 \mathrm{sec}, 58^{\circ} \mathrm{C}$ for $30 \mathrm{sec}$, and $72^{\circ} \mathrm{C}$ for $30 \mathrm{sec}$. PCR products were loaded 
Table V. Associations between renal cell carcinoma gene expression and clinical data

\begin{tabular}{|c|c|c|c|c|c|c|c|c|c|}
\hline \multirow[b]{2}{*}{ Parameter } & \multirow[b]{2}{*}{$\mathrm{n}$} & \multicolumn{2}{|c|}{ BNIP3 mRNA } & \multicolumn{2}{|c|}{$V H L$ mRNA } & \multicolumn{2}{|c|}{ HIFIA mRNA } & \multicolumn{2}{|c|}{$V E G F$ mRNA } \\
\hline & & $\mathrm{M}$ & $\mathrm{r}$ & $\mathrm{M}$ & $\mathrm{r}$ & $\mathrm{M}$ & $\mathrm{r}$ & M & $\mathrm{r}$ \\
\hline Sex & & & -0.33 & & -0.11 & & 0.01 & & 0.20 \\
\hline Male & 19 & 0.22 & & 0.46 & & 13.00 & & 16.50 & \\
\hline Female & 11 & 0.44 & & 0.51 & & 10.83 & & 11.52 & \\
\hline Age (years) & & & -0.03 & & -0.21 & & -0.10 & & -0.04 \\
\hline$<65$ & 22 & 0.30 & & 0.51 & & 12.37 & & 13.14 & \\
\hline$\geq 65$ & 8 & 0.28 & & 0.33 & & 11.03 & & 14.01 & \\
\hline Diameter of tumor & & & -0.14 & & -0.17 & & -0.07 & & 0.23 \\
\hline$<4 \mathrm{~cm}$ & 7 & 0.27 & & 0.68 & & 15.03 & & 16.50 & \\
\hline$\geq 4 \mathrm{~cm}$ & 23 & 0.34 & & 0.46 & & 10.82 & & 11.72 & \\
\hline Clinical stage & & & 0.21 & & 0.06 & & $0.84^{\mathrm{b}}$ & & $-0.37^{\mathrm{a}}$ \\
\hline I-II & 19 & 0.22 & & 0.51 & & 7.52 & & 16.50 & \\
\hline III-IV & 11 & 0.34 & & 0.51 & & 39.12 & & 10.90 & \\
\hline Pathological stage & & & 0.06 & & $-0.40^{\mathrm{a}}$ & & $0.47^{\mathrm{b}}$ & & -0.09 \\
\hline I-II & 12 & 0.30 & & 0.57 & & 6.92 & & 14.11 & \\
\hline III-IV & 18 & 0.29 & & 0.37 & & 17.56 & & 13.04 & \\
\hline Total & 30 & $0.30^{\mathrm{a}}$ & & $0.51^{*}$ & & $12.30^{\mathrm{a}}$ & & $13.14^{\mathrm{a}}$ & \\
\hline
\end{tabular}

Expression levels of BNIP3, VHL, HIF1A, and VEGF in tumor and adjacent non-tumor tissue samples from 30 cases of ccRCC were determined by RT-qPCR. Relative expression levels of each gene are shown relative to expression levels in adjacent non-tumor tissue samples, which were set as 1. M, median; r, correlation coefficient; VHL, von Hippel-Lindau; HIF1A, hypoxia-inducible factor-1 $\alpha$; VEGF, vascular endothelial growth factor; ccRCC, clear cell renal cell carcinoma; RT-qPCR, reverse transcription-quantitative polymerase chain reaction. For single-sample non-parametric test and rank correlation, ${ }^{\mathrm{a}} \mathrm{P}<0.05$; ${ }^{\mathrm{b}} \mathrm{P}<0.01$.

onto $2 \%$ agarose gels and visualized with ethidium bromide under ultraviolet (UV) light. As a control for cDNA synthesis, RT-PCR was also performed using primers specific for the GAPDH gene. RT-qPCR was performed with the reaction mixtures described in Table III. The RT-qPCR conditions were as follows: One cycle of denaturation at $95^{\circ} \mathrm{C}$ for $1 \mathrm{~min}$, followed by 40 cycles of $95^{\circ} \mathrm{C}$ for $10 \mathrm{sec}, 60^{\circ} \mathrm{C}$ for $30 \mathrm{sec}$, and $72^{\circ} \mathrm{C}$ for $30 \mathrm{sec}$. The $B N I P 3$ primers for PCR were as follows: Forward, 5'-ACCAACAGGGCTTCTGAAC-3'; reverse, 5'-GAGGGTGGCCGTGCGC-3' (204 bp). GAPDH was used as an internal control, and primers were as described above. Reactions without the cDNA template were used as blank controls. Western blotting for the analysis of protein expression was subsequently performed, as described above.

ChIP assay. Cultured cells (786-O, ACHN, and A498) for the evaluation of $B N I P 3$ promoter deacetylation were grown on $100 \mathrm{~mm}$ cell-culture dishes (Corning Incorporated) and incubated in an atmosphere of $5 \% \mathrm{CO}_{2}$ and $95 \%$ air for $24 \mathrm{~h}$. Subsequently, the medium was renewed for medium containing $1.0 \mu \mathrm{mol} / 1 \mathrm{TSA}$. Cells treated with media without TSA were used as a negative control. Cell media was renewed every $24 \mathrm{~h}$ for all groups. After the cells had been treated with TSA for $48 \mathrm{~h}$, commercial ChIP kits (Beyotime Institute of Biotechnology) were used to perform the ChIP assays. In brief, cells were fixed in formaldehyde (Sigma-Aldrich; now a branch of Merck, $\mathrm{KGaA}$ ) for 10 min, quenched with glycine solution for $5 \mathrm{~min}$, and washed twice with phosphate-buffered saline
(PBS) supplemented with PMSF. Subsequently, the cells were harvested, centrifuged $\left(4^{\circ} \mathrm{C}, 1,000 \mathrm{x}\right.$ g for $\left.2 \mathrm{~min}\right)$, resuspended in SDS lysis buffer and ice-bath sonicated (50W, 6 times for eight cycles) to break up the DNA into 20-1,000 bp fragments. After centrifugation $\left(4^{\circ} \mathrm{C}, 14,000 \mathrm{x} \mathrm{g}\right.$ for $\left.5 \mathrm{~min}\right), 500 \mu \mathrm{l}$ aliquots of the supernatant (containing DNA) were diluted to $2 \mathrm{ml}$ in ChIP dilution buffer. Input samples were used as positive controls, and collected prior to the addition of Protein $\mathrm{A}+\mathrm{G}$ agarose/salmon-sperm DNA, centrifugation $\left(4^{\circ} \mathrm{C}, 1,000 \mathrm{x} \mathrm{g}\right.$ for $1 \mathrm{~min}$ ), and the immunoprecipitates being divided into two $1 \mathrm{ml}$ samples. Anti-acetylated histone $\mathrm{H} 3$ polyclonal antibody (EMD/Merck Millipore) was added to the experimental group samples, whereas normal rabbit IgG antibodies were added to negative control samples. All samples were mixed with Protein $\mathrm{A}+\mathrm{G}$ agarose/salmon-sperm DNA, centrifuged $\left(4^{\circ} \mathrm{C}, 1,000 \mathrm{x} \mathrm{g}\right.$ for $1 \mathrm{~min}$ ), and then washed successively using Low Salt Immune Complex Wash buffer, High Salt Immune Complex Wash buffer, and LiCl Immune Complex Wash buffer once, and TE buffer twice. Bound complexes were eluted using elution buffer. DNA-protein crosslinking was reversed by incubation with $5 \mathrm{M} \mathrm{NaCl}$ for $4 \mathrm{~h}$ at $65^{\circ} \mathrm{C}$, and input samples were diluted to $100 \mu \mathrm{l}$ and incubated under the same conditions. DNA samples were subsequently purified using a DNA purification kit (Beyotime Institute of Biotechnology), according to the manufacturer's protocol. After the DNA had been purified, PCR was performed according to the protocol described in Table IV. The PCR conditions were as follows: One cycle of denaturation at $95^{\circ} \mathrm{C}$ for $1 \mathrm{~min}$, followed by 35 cycles of $95^{\circ} \mathrm{C}$ 
for $10 \mathrm{sec}, 55^{\circ} \mathrm{C}$ for $30 \mathrm{sec}$, and $72^{\circ} \mathrm{C}$ for $30 \mathrm{sec}$. Reactions containing no DNA template were used as blank controls. Reaction products were subjected to agarose gel electrophoresis (2\%), and analyzed under UV light, as described above. The BNIP3 ChIP primers employed in these analyses were as follows: 5'-AGCGGGAAATTGAGAAAGCGA-3' (forward) and 5'-TCCATCCTGCTAGTGGGGAA-3' (reverse; 548 bp).

Statistical analysis. Data associated with the tissue samples are presented as the median and the inter-quartile range (IQR). Statistically significant differences were determined using a single-sample non-parametric test, correlation analyses were determined by rank correlation, and $\mathrm{P}<0.05$ was taken to indicate a statistically significant value. Data from cultured cells are presented as the mean \pm standard error (SE). Unpaired t-tests were used for determining statistically significant differences, which were defined as $\mathrm{P}<0.05$.

\section{Results}

Expression levels of BNIP3 and associated genes in RCC tissue samples and cultured cells. RT-qPCR was used to examine the mRNA expression levels of BNIP3 and associated genes. In tissue samples collected from patients with ccRCC, BNIP3 and VHL expression levels were lower in tumor tissues compared with those in adjacent non-tumor tissues, with median relative transcript levels of 0.30 (IQR=0.17-0.44; $\mathrm{P}<0.05)$ and $0.51(\mathrm{IQR}=0.34-0.69 ; \mathrm{P}<0.05)$, respectively (the relative expression level of each gene is shown relative to levels in adjacent non-tumor control tissue samples, which were set to 1) (Table V). However, the mRNA expression levels of HIFIA and VEGF were higher in tumor tissues compared with adjacent non-tumor tissues, with median relative transcript levels of $12.30(\mathrm{IQR}=6.92-34.98 ; \mathrm{P}<0.05)$ and 13.14 (IQR=9.30-24.73; $\mathrm{P}<0.05)$, respectively.

Statistical analysis of the gene expression data, according to the clinical characteristics of the tumors, indicated that VHL mRNA expression was negatively correlated with pathological tumor stage $(\mathrm{r}=-0.40 ; \mathrm{P}<0.05)$, whereas no significant correlations with gender, age, size of tumor, or clinical stage were detected ( $\mathrm{P}>0.05$; Table V). Furthermore, the expression of HIF IA was positively correlated with the pathological and clinical tumor stage $(\mathrm{r}=0.84,0.47 ; \mathrm{P}<0.01)$; however, no significant correlations were observed for gender, age, or the size of tumor $(\mathrm{P}>0.05)$. VEGF expression was negatively correlated with clinical tumor stage $(r=-0.40$; $\mathrm{P}<0.05)$, but there were no significant correlations with gender, age, size of tumor or pathological stage $(\mathrm{P}>0.05)$. There were no significant correlations between BNIP3 mRNA expression levels and gender, age, size of tumor, or clinical or pathological stage $(\mathrm{P}>0.05)$. Likewise, there were there no significant correlations among the expression levels of BNIP3, VHL, HIF1A, and VEGF.

To explore protein expression in RCC, western blots were performed, which revealed reduced levels of BNIP3 and VHL in RCC tumors compared with adjacent non-tumor tissue samples (relative expression levels, 0.56 and 0.23 , respectively; P<0.05; Fig. 1A). In contrast, HIF-1 $\alpha$ and VEGF were expressed at significantly higher levels in tumor tissue samples (1.12 and 3.45, respectively; $\mathrm{P}<0.05)$.
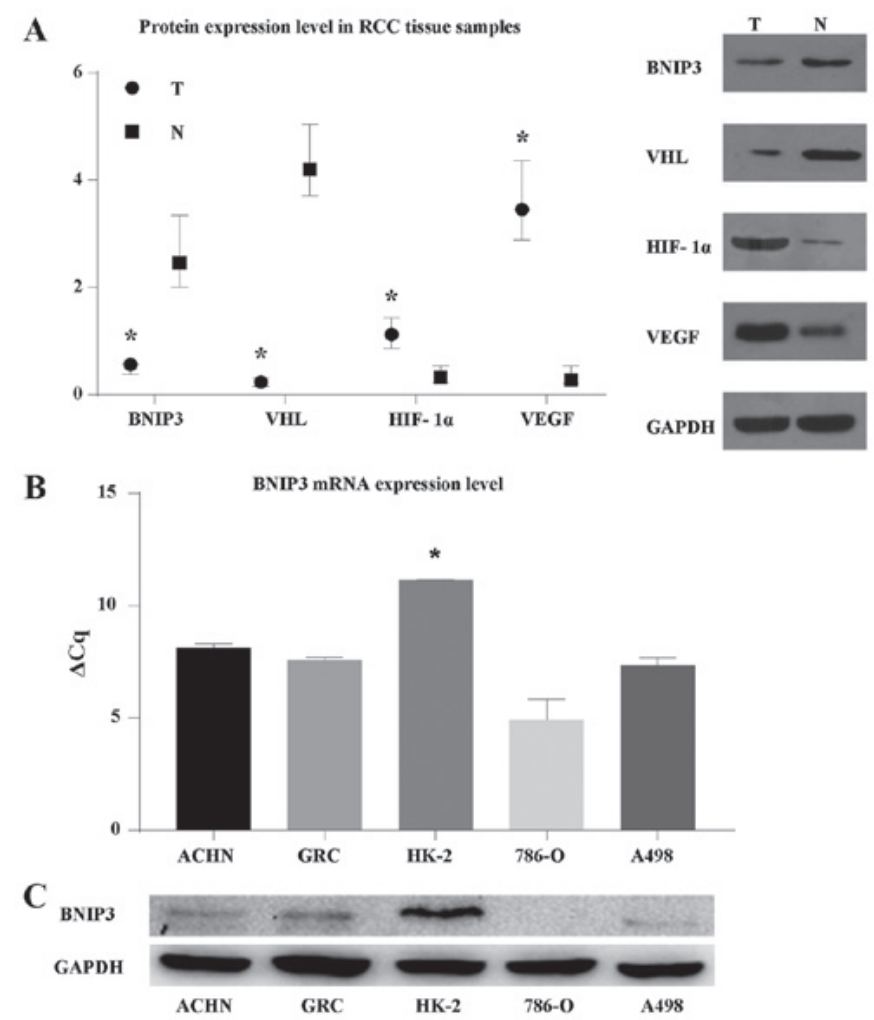

Figure 1. BNIP3 expression in ccRCC tumor tissue samples, adjacent non-tumor tissue samples, and cell lines. (A) Relative protein expression levels of BNIP3, VHL, HIF-1 $\alpha$, and VEGF in tumor and adjacent non-tumor tissue samples from 30 cases of ccRCC were determined by WB using the levels of GAPDH as an internal control. Data are presented as the median and inter-quartile range. $\mathrm{T}$, tumor tissues; $\mathrm{N}$, adjacent non-tumor tissues. ${ }^{*} \mathrm{P}<0.05$ compared with adjacent non-tumor tissues. Representative examples are shown. (B) RT-qPCR, demonstrating that BNIP3 mRNA expression was significantly lower in 786-O, ACHN, A498 and GRC-1-1 RCC cells (particularly 786-O cells) compared with normal renal HK-2 cells. BNIP3 mRNA expression levels were measured as percentages of that of HK-2. ${ }^{*} \mathrm{P}<0.05$ compared with ACHN, GRC-1-1, 786-O, A498 cells. (C) BNIP3 protein levels in 786-O, ACHN, A498, GRC-1-1, and HK-2 cells were evaluated by WB, with GAPDH as a control. A representative example is shown. WB, western blotting; VHL, Hippel Lindau; HIF-1 $\alpha$, hypoxia-inducible factor-1 $\alpha$; VEGF, vascular endothelial growth factor; ccRCC, clear cell renal cell carcinoma; RT-qPCR, reverse transcription-quantitative polymerase chain reaction.

For cultured cells, RT-qPCR demonstrated that BNIP3 expression levels were lower in all RCC cell lines investigated (786-O, ACHN, A498, and GRC-1-1; P<0.05; Fig. 1B) when compared with the normal human renal tubular epithelial cell line, HK-2, with relative transcript levels of $1.5,12,7$ and $8 \%$, respectively. As expected, western blots of cultured cells demonstrated reduced levels of BNIP3 in the 786-O, ACHN, and A498 lines compared with the HK-2 cell line (Fig. 1C); these findings were consistent with the RT-qPCR results.

Methylation status of the BNIP3 gene promoter region in $R C C$. Our results indicated a reduced $B N I P 3$ expression in RCC tissues and cells, which may have been caused by methylation of its promoter region (17). To determine whether the promoter region of $B N I P 3$ was methylated, and to explore the epigenetic regulation of this gene in RCC, MS-PCR was performed (Fig. 2A). The human colorectal cancer cell line, SW480, in which the BNIP3 promoter region is methylated, was chosen 


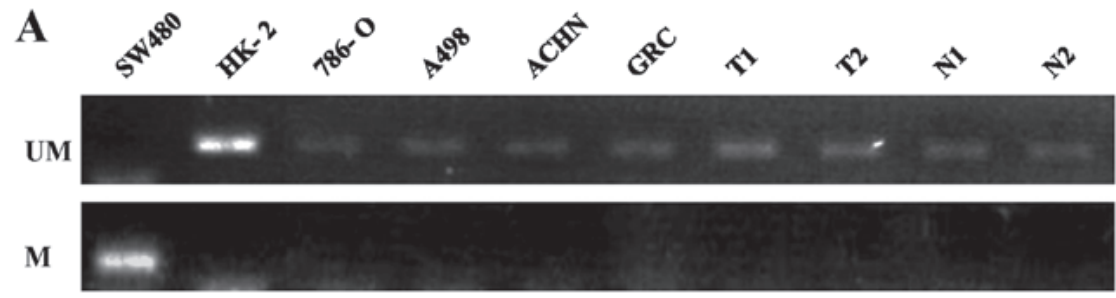

\section{B}
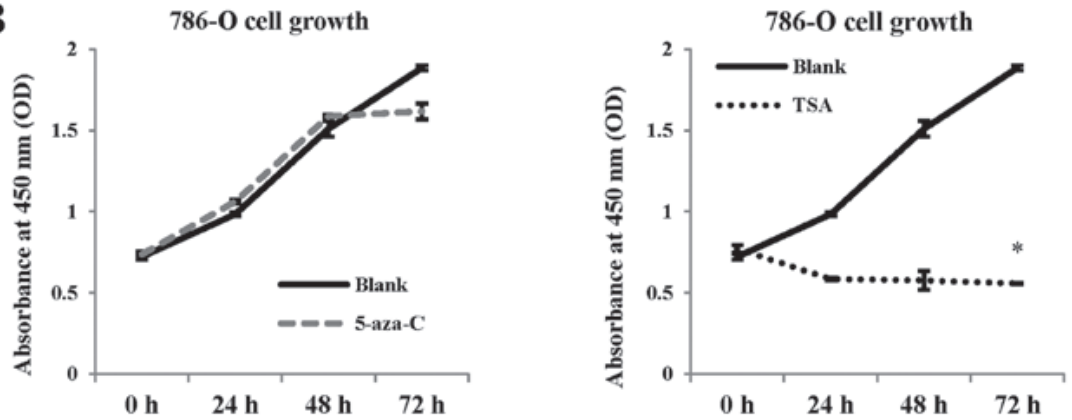

Figure 2. Methylation status of the BNIP3 promoter in RCC cells. (A) Methylation-specific PCR analysis of the colorectal cancer cell line, SW480, the normal renal cell line, HK-2, the RCC cell lines, 786-O, A498, ACHN, and GRC-1-1, and RCC tumor tissues (T) and adjacent non-tumor tissues (N) from 30 cases with RCC. The BNIP3 promoter was methylated in SW480 cells, which was set as a positive control. No methylation was observed in the HK-2 cells or in the 30 samples of RCC adjacent non-tumor tissues; this was also the case for the 786-O, A498, ACHN, and GRC-1-1 cell lines, and 30 samples of RCC tumor tissues (two representative cases are presented here). M, methylated; UM, unmethylated. (B) 786-O cells, which showed the lowest expression levels of BNIP3 among the four RCC cell lines investigated, were cultured with or without 5-aza-C or TSA for $72 \mathrm{~h}$. Cells treated with no drugs were set as a blank control. Tumor cell proliferation was examined using the Cell Counting Kit-8. No significant differences were found between the 5-aza-C group and the untreated group; however, TSA significantly inhibited RCC cell growth compared with the blank group. * $\mathrm{P}<0.05$ compared with the blank group. 5 -aza-C, 5-aza-cytidine; TSA, trichostatin A; RCC, renal cell carcinoma; PCR, polymerase chain reaction.

as a positive control. Our analysis failed to identify evidence of any methylation in the BNIP3 promoter region in either the HK-2 cells or the adjacent non-tumor tissues, in addition to the 786-O, ACHN, and A498 RCC cell lines and the patient ccRCC tumor samples, suggesting that reduced BNIP3 expression in RCC is not likely to be due to methylation of the BNIP3 promoter region.

Subsequently, tumor cells were treated with the demethylation inhibitor, 5-aza-C, and their proliferation was examined. In the presence of a methylated BNIP3 promoter region in $\mathrm{RCC}$ cells, treatment with 5-aza-C would be expected to induce the upregulation of $B N I P 3$, and the consequential promotion of apoptosis. The cell line 786-O, which exhibited low BNIP3 expression, was chosen for the 5-aza-C treatment experiments. The findings of this experiment revealed that there were no significant differences in proliferation following demethylation treatment, consistent with the results of MS-PCR (Fig. 2B).

As previously published studies have reported that certain tumors with reduced BNIP3 expression exhibit histone deacetylation $(18,20)$, RCC cells were also treated with trichostatin A (TSA), a type of histone deacetylase inhibitor (HDACI). Treatment with TSA inhibited the growth of tumor cells by $70.4 \%$ after $72 \mathrm{~h}$ treatment $\left(\mathrm{IA}_{\mathrm{TSA}}-\mathrm{A}_{\mathrm{Blank}} \mathrm{I} / \mathrm{A}_{\mathrm{Blank}}\right.$; $\mathrm{P}<0.05$; Fig. 2B). This led us to hypothesize that the inhibition of deacetylation might activate BNIP3 expression.

Treatment with an HDACI suppresses tumor proliferation and promotes apoptosis. To test our hypothesis that BNIP3 expression might be activated by inhibiting deacetylation, the proliferation levels of 786-O, A498, and ACHN cells were examined following treatment with different concentrations of TSA $(0.5,1.0$, and $2.0 \mu \mathrm{mol} / \mathrm{l})$ (Fig. 3A). The absorbance values at $450 \mathrm{~nm}$ of TSA-treated cells were significantly lower compared with those of the controls $(\mathrm{P}<0.05)$; however, no significant differences were detected among different cell lines $(\mathrm{P}>0.05)$, and no concentration-dependence inhibition effects of TSA upon cell proliferation were observed.

Apoptosis was also examined in cultured cells exposed to HDACI by using Annexin V-FITC flow cytometric analysis (Fig. 3B). As shown in Fig. 3B, after TSA-treatment for 48 h, levels of early apoptotic (EA) cells were significantly increased $(\mathrm{P}<0.05)$, with no significant differences noted among cultured cells or in response to different concentrations of TSA. Levels of late apoptotic (LA) and necrotic 786-O cells were significantly increased $(\mathrm{P}<0.05)$. Consequently, it appears that the inhibition of deacetylation may suppress tumor growth, and promote apoptosis.

Treatment with TSA leads to the upregulation of BNIP3 expression. As our results indicated that HDACI caused RCC cell death, whether TSA treatment could activate BNIP3 expression was subsequently investigated. Therefore, RT-qPCR on cultured cells treated with TSA at different concentrations $(0.5,1.0$, and $2.0 \mu \mathrm{mol} / \mathrm{l})$ was performed (Fig. 4A). After treatment for $24 \mathrm{~h}$, BNIP3 mRNA expression markedly increased in all three RCC cell lines (786-O, A498, and $\mathrm{ACHN}$; $\mathrm{P}<0.05)$. In 786-O cells, expression levels for each TSA concentration $(0.5,1.0$ and $2.0 \mu \mathrm{mol} / \mathrm{l})$ were determined to be 247,395 , and 366 times higher compared with the controls $(\mathrm{P}<0.05)$, although no significant differences were observed among cells treated with each TSA concentration ( $\mathrm{P}>0.05)$. However, for the other two cell lines (A498 and $\mathrm{ACHN}$ ), the increases in expression were less pronounced 

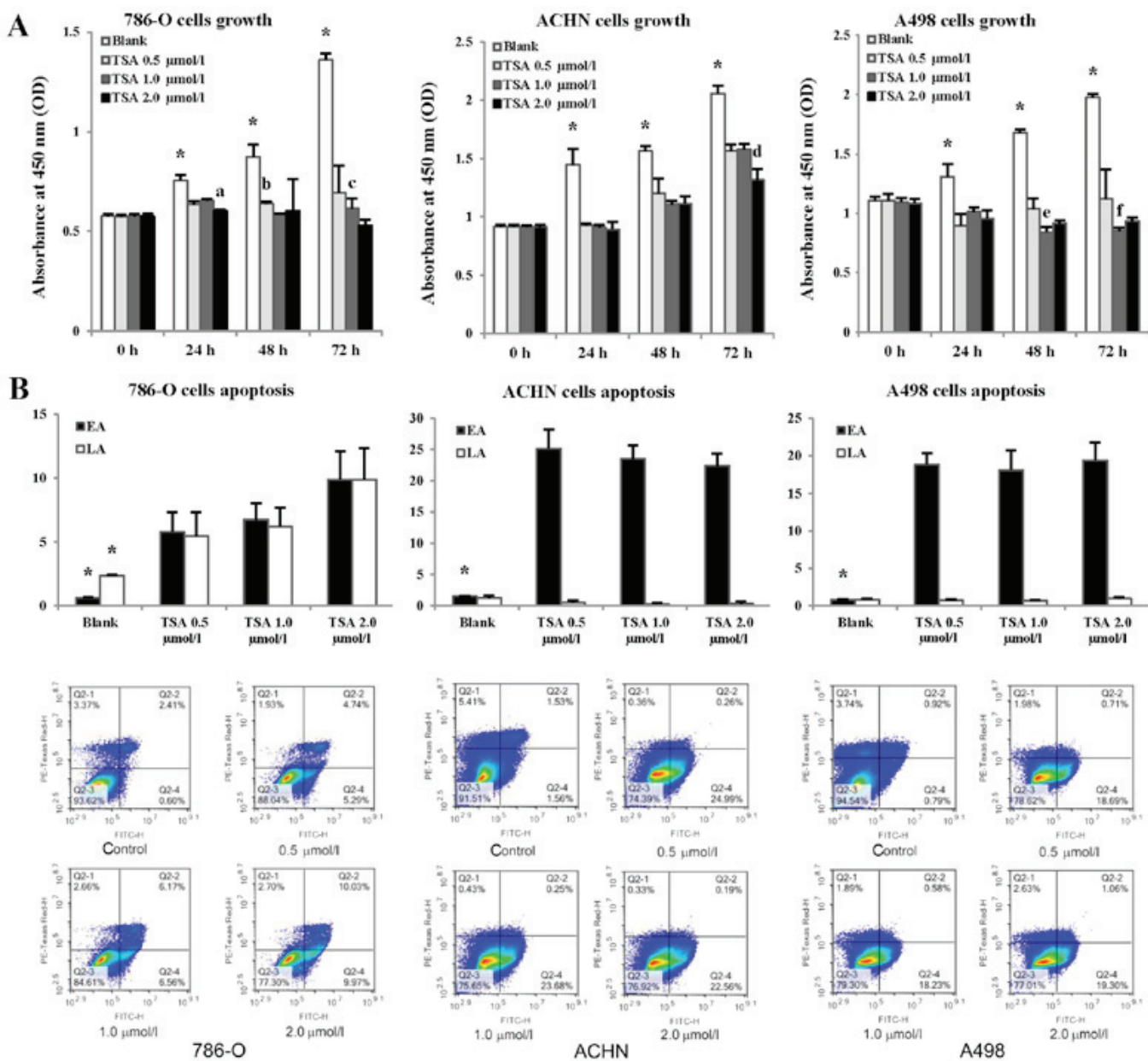

Figure 3. Evaluation of RCC cell proliferation and apoptosis following treatment with TSA. (A) 786-O, ACHN, and A498 cells were treated with different concentrations of TSA $(0.5,1.0$, and $2.0 \mu \mathrm{mol} / 1)$. Untreated cells were used as the control group (blank), and cell proliferation was evaluated using Cell Counting Kit- 8 assay every $24 \mathrm{~h}$ for $72 \mathrm{~h} .{ }^{*} \mathrm{P}<0.05$ compared with each TSA-treated group; ${ }^{a} \mathrm{P}<0.05$ compared with TSA 0.5 and $1.0 \mu$ mol/l treatment groups for 786-O after $24 \mathrm{~h}$ treatment; ${ }^{b} \mathrm{P}<0.05$ compared with the TSA $1.0 \mu \mathrm{mol} / 1$ treatment group for $786-\mathrm{O}$ after $48 \mathrm{~h}$ treatment; ${ }^{\mathrm{c}} \mathrm{P}<0.05$ compared with the TSA $2.0 \mu \mathrm{mol} / 1$ treatment group for $786-\mathrm{O}$ after $72 \mathrm{~h}$ treatment; ${ }^{\mathrm{d}} \mathrm{P}<0.05$ compared with the TSA 0.5 and $1.0 \mu \mathrm{mol} / 1$ treatment groups for ACHN after $72 \mathrm{~h}$ treatment; ${ }^{\mathrm{P}} \mathrm{P}<0.05$ compared with the TSA 0.5 and $2.0 \mu \mathrm{mol} / 1$ treatment groups for A498 after $48 \mathrm{~h}$ treatment; ${ }^{\mathrm{f}} \mathrm{P}<0.05 \mathrm{compared}$ with the TSA $2.0 \mu \mathrm{mol} / 1$ treatment group for A498 after $72 \mathrm{~h}$ treatment. (B) Three cells lines were treated with TSA at different concentrations, and untreated cells were used as controls (blank). Apoptosis was evaluated using Annexin V-FITC flow cytometric analysis, with concentration of cells for flow cytometry was $2 \times 10^{5} / \mathrm{ml}$. FITC-H binds to Annexin V, an increase of which indicates elevated EA, whereas PE-Texas Red H binds propidium iodide, an increase of which indicates elevated LA. Histograms show the apoptotic status of RCC cells. ${ }^{*} \mathrm{P}<0.05$ compared with each TSA treatment group. Representative flow cytometric scatter plots are presented under the histograms. Each quarter in the coordinate system represents a different cell status, and the proportional change in each quarter reflects the effect of TSA treatment on cells. Q2-1, cells that have sustained mechanical injury; Q2-2, late apoptotic and necrotic cells; Q2-3, normal cells; Q2-4, early apoptotic cells. EA, early apoptosis; LA, late apoptosis; RCC, renal cell carcinoma; TSA, trichostatin A; FITC, fluorescein isothiocyanate.

compared with those observed in the 786-O cell line. For the cell lines ACHN and A498, significant differences were identified between cells treated with 0.5 and 1.0 , and 0.5 and $2.0 \mu \mathrm{mol} / 1 \mathrm{TSA}(\mathrm{P}<0.05)$, although no significant differences were identified between cells treated with 1.0 and $2.0 \mu \mathrm{mol} / 1$ TSA $(\mathrm{P}>0.05)$.

Western blotting was also performed to explore BNIP3 protein expression following treatment with TSA (Fig. 4B). BNIP3 protein was hardly expressed at all in the 786-O, A498, or ACHN cells prior to treatment. However, following the addition of TSA $(0.5$ or $1.0 \mu \mathrm{mol} / \mathrm{l})$ for $48 \mathrm{~h}$, BNIP3 protein expression markedly increased $(\mathrm{P}<0.05)$, with the most pronounced increase observed for 786-O cells, consistent with the RT-qPCR results. Although the difference in BNIP3 expression recorded for 786-O cells treated with either 0.5 or $1.0 \mu \mathrm{mol} / 1 \mathrm{TSA}$ was statistically significant $(\mathrm{P}<0.05)$, this was not the case for the other two cell lines investigated (ACHN and A498 cells; $\mathrm{P}>0.05)$. Taken together, the results of the RT-qPCR and western blotting experiments indicated that TSA treatment activated BNIP3 expression in RCC.

Histone deacetylation of the BNIP3 promoter region in $R C C$ cells. As our results indicated that HDACI treatment led to an increase in BNIP3 expression and the induction of apoptosis in RCC cells, subsequently the histone deacetylation status of the BNIP3 promoter region in RCC cells was determined, as this could have provided an explanation for the effects of TSA. ChIP assays demonstrated that histone $\mathrm{H} 3$ was deacetylated in the BNIP3 promoter region in 786-O and $\mathrm{ACHN}$ cells, and that histone $\mathrm{H} 3$ became acetylated after $48 \mathrm{~h}$ treatment with TSA $(1.0 \mu \mathrm{mol} / 1$, Fig. 5). However, there was no change in histone $\mathrm{H} 3$ acetylation in the A498 cells following treatment with TSA. 

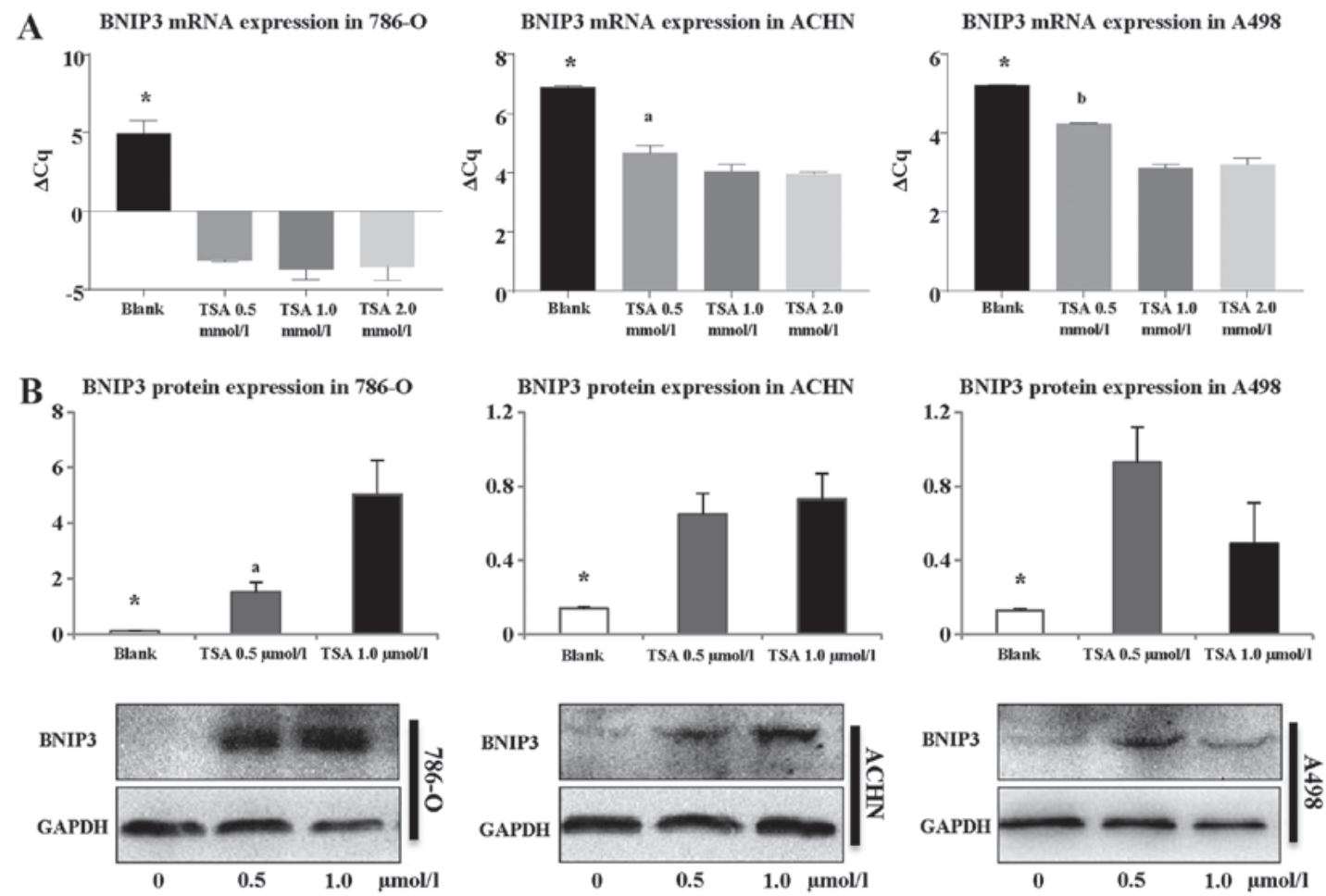

Figure 4. BNIP3 expression in 786-O, A498, and ACHN cells following treatment with TSA. (A) Expression of BNIP3 mRNA in 786-O, ACHN and A498 cells was quantified by RT-qPCR after treatment with TSA for $24 \mathrm{~h}$. The untreated controls (blank) for each of the three cell lines were assigned a relative value of $1 .{ }^{*} \mathrm{P}<0.05$ compared with treatment groups $\left({ }^{\mathrm{a}} \mathrm{P}<0.05\right.$ compared with TSA 1.0 and $2.0 \mu \mathrm{mol} / 1$ treatment groups for ACHN cells; ${ }^{b} \mathrm{P}<0.05$ compared with TSA 1.0 and $2.0 \mu \mathrm{mol} / 1$ treatment groups for A498 cells). (B) BNIP3 protein levels in 786-O, ACHN, and A498 cells following TSA treatment for $48 \mathrm{~h}$ were examined by western blotting. GAPDH was used as an internal control, and cells cultured without TSA were considered as untreated controls (Blank). ${ }^{*} \mathrm{P}<0.05$ compared with treatment groups ( ${ }^{a} \mathrm{P}<0.05$ compared with the TSA $1.0 \mu \mathrm{mol} / 1$ treatment group). Representative bands are presented under the histograms. TSA, trichostatin A; RT-qPCR, reverse transcription-quantitative polymerase chain reaction.
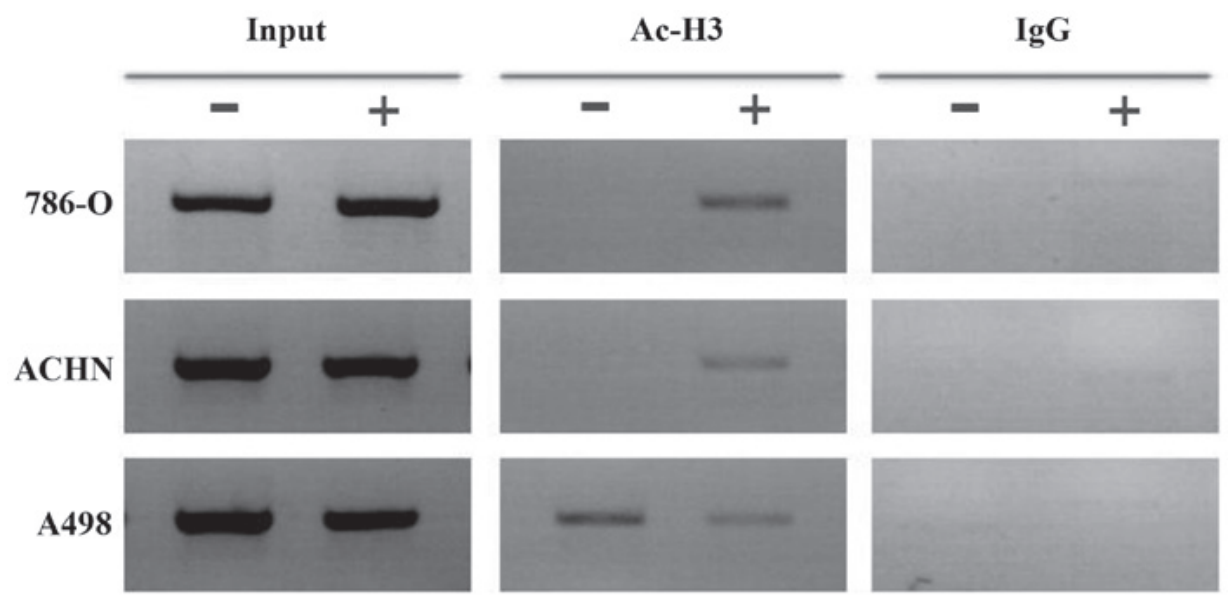

Figure 5. Deacetylation status of the BNIP3 promoter in 786-O, A498 and ACHN cells before and after TSA treatment. Chromatin immunoprecipitation was used to evaluate the deacetylation status of the BNIP3 promoter. The treatment group was treated with $1.0 \mu \mathrm{mol} / 1 \mathrm{TSA}$ for $48 \mathrm{~h}$. Input DNA was used as a positive control, and extracts were incubated with IgG as a negative control. Ac-H3, polyclonal antibody against acetylated histone H3; -, non-TSA-treatment group; +, TSA-treatment group; TSA, trichostatin A; IgG, immunoglobulin G.

\section{Discussion}

The BNIP3 protein exhibits homology with the BH3 domain of B-cell lymphoma $2(\mathrm{Bcl}-2)$ protein, and is an atypical member of the BH3-only subfamily (21). The mechanisms that connect mitophagy with apoptosis are complicated, and these include synergistic, antagonistic, and stimulatory effects; BNIP3 also connects mitophagy with apoptosis, thus affecting the ultimate fate of cells (22-26). BNIP3 is able to induce mitochondrial autophagy in response to environmental changes to promote cell survival; however, under seriously detrimental environmental conditions, excessive mitochondrial autophagy is induced, leading to apoptosis (27) (Fig. 6). The expression of BNIP3 in different tumors has been shown to be inconsistent, as high expression levels of BNIP3 have been reported in numerous other tumor types, including prostate 
cancer, spongioblastoma, endometrial carcinoma, cervical cancer, invasive breast cancer and lung cancer, to cite a few examples (28). Furthermore, low levels of BNIP3 expression have been observed in pancreatic cancer, gastric carcinoma, colorectal cancer and ccRCC (28). Either BNIP3 activation or silencing has been shown to promote tumor invasion, delay cell death, and subsequently lead to poor prognosis in different types of tumor (14,29-32). However, the regulatory mechanism of BNIP3 in ccRCC has yet to be elucidated.

As a hypoxia-responsive gene downstream of HIF, BNIP3 was originally considered to be overexpressed in response to HIF upregulation; however, according to a study which examined 104 RCC tumor samples and 48 adjacent non-tumor tissue samples, the lower levels of BNIP3 expression in tumor tissues was not accompanied by high expression levels of HIF-1 $\alpha$ and VEGF in ccRCC (13). The present study revealed that the expression of BNIP3 and VHL in tumor tissues was lower compared with adjacent non-tumor tissues, whereas the expression of HIF-1 $\alpha$ and VEGF was higher in tumor tissues at the mRNA and protein levels. Furthermore, low levels of BNIP3 expression were also observed in RCC cell lines. These results suggest that the BNIP3 pathway may be blocked in a certain way, although the hypoxia/HIF-1 pathway remains intact, and HIF-1 continues to be normally activated in RCC.

As previously described, BNIP3 silencing might facilitate tumor survival. According to a study by Erkan et al (32), the loss of BNIP3 expression contributes to chemoresistance and poor prognosis in pancreatic cancer. In another study, Okami et al (17) described the contribution of BNIP3 silencing to the aggressive nature of pancreatic cancer. A reduced expression of BNIP3 has also been reported in cases of chemotherapy-resistant colon cancer $(33,34)$. In the present study, no association was identified between BNIP3 expression level and any of the pathological parameters examined in patients with RCC. This may be due to the relatively low number of samples included in this study, and additional studies featuring a larger number of samples will be required to obtained more conclusive results. In addition, VHL expression was also shown to be negatively correlated with the tumor pathological stage, whereas that of HIF-1 $\alpha$ exhibited the opposite correlation, suggesting that the HIF-1 pathway may have a role in the progression of RCC. VEGF acts downstream of HIF-1; however, our study demonstrated a negative correlation between VEGF and clinical parameters, a finding which was not consistent with the results of previous studies $(13,35)$. Again, a larger sample size is required in order to confirm these findings.

Epigenetic regulation, a modulation of gene expression that does not rely on changes in the DNA sequence, can be stably inherited in proliferating cells. DNA methylation and histone deacetylation are two epigenetic mechanisms with crucial roles in tumorigenesis and tumor progression. Hypermethylation always occurs at $\mathrm{CpG}$ islands, which were originally defined as regions of DNA with a $\mathrm{G}+\mathrm{C}$ ratio $>0.5$ and an observed vs. expected frequency of CpGs, which was shown to be $>0.6$ (36). The majority of $\mathrm{CpG}$ islands are associated with promoter regions of housekeeping or tissue-specific genes (37), and CpG hypermethylation contributes to the functional inactivation of genes involved in growth regulation (38) and DNA repair (39).

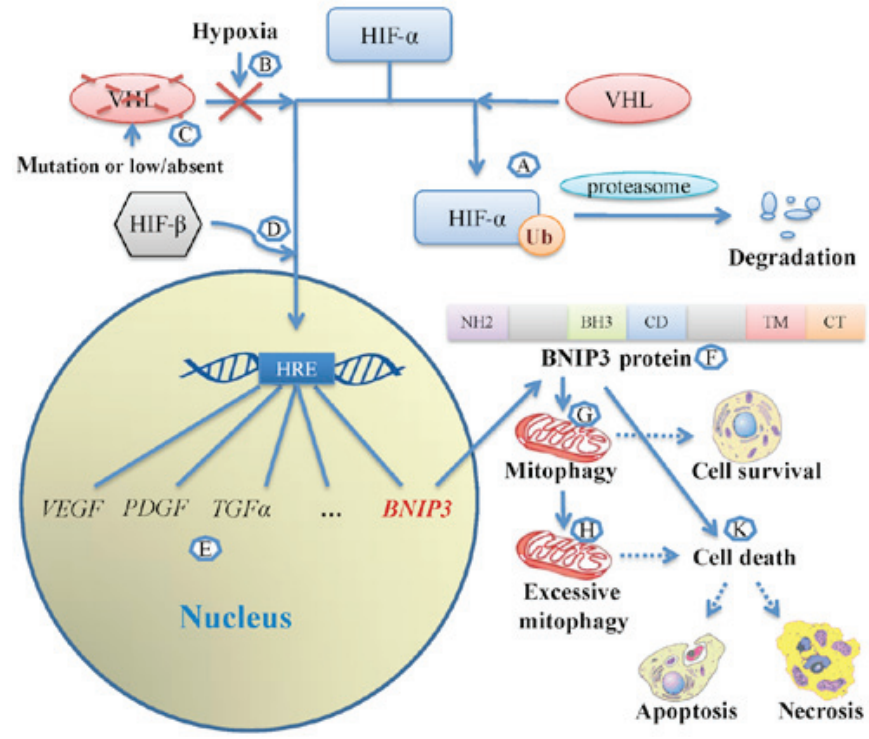

Figure 6. Mechanistic aspects of the VHL-HIF-BNIP3 signaling pathway. Step A: The binding of HIF- $\alpha$ to VHL and to the E3 ligase complex causes HIF- $\alpha$ to be ubiquitinated and marked for degradation by the cell's proteasomal complex. Step B: In a hypoxic environment, HIF- $\alpha$ cannot bind the VHL protein, and consequently cannot be degraded. Step C: Aberrant functioning of VHL also leads to an accumulation of HIF $\alpha$. Step D: HIF- $\alpha$ levels rise in the cell, allowing the protein to bind with HIF $\beta$. The HIF- $\alpha / \beta$ heterocomplex may be translocated to the nucleus and bind to specific HREs. Step E: HREs activates downstream genes, including VEGF, PDGF, TGF $\alpha$, and several others, which have important roles in tumor growth and progression. BNIP3 can also be activated by HREs. Step F: Structure of the BNIP3 protein: NH2, N-terminal domain; BH3, Bcl-2 homology domain 3; $\mathrm{CD}$, conserved domain; TM, transmembrane domain; CT, COOH-terminal domain; Step G: BNIP3 can induce mitochondrial autophagy in response to environmental changes to promote cell survival. Step H: Under seriously detrimental environmental conditions, excessive mitochondrial autophagy is induced, leading to apoptosis. Step K: BNIP3-induced cell death is also activated under conditions of extreme hypoxia, acidosis and NO. Ub, ubiquitin; HRE, hypoxia-response element; VHL, Hippel-Lindau; HIF-1 $(\alpha / \beta)$, hypoxia-inducible factor-1 $(\alpha / \beta)$; VEGF, vascular endothelial growth factor; PDGF, platelet-derived growth factor; TGF $\alpha$, transforming growth factor $\alpha$.

The modification of histones leads to alterations in the interactions between DNA and histones, thus influencing chromatin tension and, subsequently, the regulation of transcription. Deacetylation is the most important mechanism involved in histone modification, which leads to the inhibition or silencing of genes, including tumor suppressor genes.

DNA methylation is a proven mechanism of BNIP3 downregulation in tumors. In a previous study, Murai and coworkers demonstrated that BNIP3 was methylated in $65.6 \%$ of colorectal cancer tissues, although it was not methylated in adjacent normal tissue samples $(15,40)$. Similarly, Cleven et al (41) also demonstrated the occurrence of BNIP3 methylation in $52.8 \%$ of colorectal cancer cells, and that treatment with 5 -aza-C restored the expression of $B N I P 3$ and led to increased apoptosis and autophagy, with enhanced sensitivity to chemotherapy. In another study, Okami et al (17) and Abe et al (42) observed methylation of the BNIP3 promoter in pancreatic cancer. In the current study, no methylation was detected in the BNIP3 promoter region of either RCC tissues or cell lines. In addition, treatment with 5-aza-C did not induce any changes in RCC cell proliferation. These data suggest that the downregulation of BNIP3 in RCC 
is not induced by methylation, but, instead, is a consequence of histone deacetylation.

Murai et al (20) and Bacon et al (18) treated colorectal cancer cells with the HDACI, TSA, leading to BNIP3 upregulation; Murai et al (40) also identified histone acetylation of the BNIP3 promoter region. In the present study, the mRNA and protein expression levels of BNIP3 were increased following treatment of the RCC 786-O, ACHN, and A498 cell lines with TSA, and ChIP assays demonstrated histone deacetylation in the BNIP3 promoter region of 786-O and ACHN RCC cells, with the acetylation status restored following TSA treatment. Therefore, it may be concluded that histone deacetylation is a primary cause of BNIP3 inactivation in RCC.

However, A498 RCC cells did not exhibit histone deacetylation in the BNIP3 promoter, and treatment with TSA led to an increase in BNIP3 expression with no changes detected in the BNIP3 promoter. Bacon et al (18) previously found that BNIP3 was upregulated following either 5-aza-C or TSA treatment in certain types of colorectal cancer cells, which had no initial methylation or histone deacetylation in the BNIP3 promoter region. This observation suggests that other mechanisms, and not only histone deacetylation, are involved in the inactivation of BNIP3 in RCC.

As a HDACI, TSA is known to reverse the deacetylated status of histones (43), which could possibly play a role in the mechanisms described above. The growth inhibition and apoptosis induction characteristics of TSA have also been established in several types of tumor cells (44). Similarly to BNIP3, the expression of numerous other genes, including p27 (45), increased following TSA treatment in RCC, which leads to the promotion of cell apoptosis. Along with the increased expression of several genes, TSA is able to activate a range of signaling pathways, including the c-Jun N-terminal kinase (JNK) signaling pathway (46), to promote cell apoptosis, or it can suppress pathways, such as the Wnt/beta catenin signaling pathway (47). However, the mechanisms according to which these pathways interact, both with each other and with BNIP3, have yet to be elucidated, and further studies are therefore required.

In the present study, no concentration-dependent effects for TSA treatment on cell proliferation and apoptosis were observed, possibly since the concentrations that were selected for comparison were too high, and the difference between the selected concentrations was relatively small. Additionally, no significant differences in the expression levels of BNIP3 mRNA were observed when comparisons were made between groups treated with 1.0 or $2.0 \mu \mathrm{mol} / 1 \mathrm{TSA}$. Hence, in subsequent Western blotting experiments, the TSA 0.5 and $1.0 \mu \mathrm{mol} / 1$ treatment groups were selected for comparison, and only the $1.0 \mu \mathrm{mol} / 1 \mathrm{TSA}$ treatment group was selected for the ChIP assay as the largest effects were observed in this group in our initial experiments.

Since the advent of molecular-targeted drugs, significant progress has been made in terms of renal cancer treatment. Agents acting on targets in the VHL-HIF hypoxia-response gene pathway have increased the rate of disease control to almost 80\%; however, according to the Response Evaluation Criteria In Solid Tumors (RECIST), targeted therapies mostly lead to stable disease, with low objective response rates (48). As a gene downstream of HIF, BNIP3 encodes a mitochondrial pro-apoptotic protein which has an important role in the biological behavior of renal carcinoma cells. Research geared towards the development of new methods for restoring BNIP3 expression and promoting its effects in causing RCC tumor cell death may provide novel options for RCC treatment; however, the demonstration of the mechanism of BNIP3 inactivation in $\mathrm{RCC}$ in the present study was restricted to in vitro experiments, and our findings require further confirmation in an animal model. In addition, as a broad-spectrum HDAC, TSA is able to induce tumor cell apoptosis in several different ways. The specific blocking and restoration of BNIP3 expression are now required to further explore the role of BNIP3 in the molecular pathogenesis of RCC.

In conclusion, in the present study low levels of expression of the pro-apoptosis gene, BNIP3, were demonstrated in RCC cells with VHL inactivation and HIF upregulation, and BNIP3 promoter methylation did not contribute to BNIP3 suppression. TSA treatment was demonstrated to restore the acetylated status of the BNIP3 gene, increase BNIP3 expression at both the mRNA and protein levels, inhibit cell proliferation, and induce RCC cell death, thereby indicating that deacetylation of the promoter region histone appears to be a mechanism of BNIP3 inactivation, and that BNIP3 could be a potential new target for RCC treatment.

\section{Acknowledgments}

We would like to thank Professor Qiao Zhou, Dr Miao Xu, Dr Mengni Zhang and Dr Junya Tan for their support with techniques and equipment.

\section{Funding}

This study was supported by the National Natural Science Foundation of China (no. 81672552), the Basic Applied Plan of Sichuan Provincial Science and Technology Department (no. 2014JY0085), and the 1.3.5 project for disciplines of excellence, West China Hospital, Sichuan University (no. ZY2016104).

\section{Availability of data and materials}

The datasets described in the study are available from the corresponding author on reasonable request.

\section{Authors' contribution}

XL designed the study, guided experiments, carried out analysis and reviewed the manuscript. YS contributed to the study design, performed experiments with cell lines, collected and analyzed data, and wrote the manuscript. ZL contributed to the study design, performed experiments (sample collection and cell lines) and wrote the manuscript. JBL and TL contributed to the study design, performed experiments of cell lines and reviewed the manuscript. HW and LH contributed to the study design, collected samples, performed experiments with tissue sample and reviewed the manuscript. JYL, QW, $\mathrm{HZ}$, and GH contributed to the study design, helped with sample collection and the preparation of cell lines, analyzed data and reviewed the manuscript. 


\section{Ethics approval and consent to participate}

This research was approved by the West China Hospital of Sichuan University Biomedical Research Ethics Committee (Chengdu, China), and informed consent was obtained from each patient.

\section{Patient consent for publication}

Not applicable.

\section{Competing interests}

The authors declare that they have no competing interests.

\section{References}

1. Subramanian VS, Stephenson AJ, Goldfarb DA, Fergany AF Novick AC and Krishnamurthi V: Utility of preoperative renal artery embolization for management of renal tumors with inferior vena caval thrombi. Urology 74: 154-159, 2009.

2. Clark PE: The role of VHL in clear-cell renal cell carcinoma and its relation to targeted therapy. Kidney Int 76: 939-945, 2009.

3. Motzer RJ, Hutson TE, Tomczak P, Michaelson MD, Bukowski RM, Rixe O, Oudard S, Negrier S, Szczylik C, Kim ST, et al: Sunitinib versus interferon alfa in metastatic renal-cell carcinoma. N Engl J Med 356: 115-124, 2007.

4. Bultitude MF: Campbell-Walsh Urology. 10th edition. BJU International, New York, NY, 2012.

5. Guo K, Searfoss G, Krolikowski D, Pagnoni M, Franks C, Clark K, Yu KT, Jaye M and Ivashchenko Y: Hypoxia induces the expression of the pro-apoptotic gene BNIP3. Cell Death Differ 8: 367-376, 2001.

6. Gunaratnam L, Morley M, Franovic A, de Paulsen N, Mekhail K, Parolin DA, Nakamura E, Lorimer IA and Lee S: Hypoxia inducible factor activates the transforming growth factor-alpha/epidermal growth factor receptor growth stimulatory pathway in VHL(-/-) renal cell carcinoma cells. J Biol Chem 278: 44966-44974, 2003.

7. Yasuda M, Theodorakis P, Subramanian T and Chinnadurai G: Adenovirus E1B-19K/BCL-2 interacting protein BNIP3 contains a BH3 domain and a mitochondrial targeting sequence. J Biol Chem 273: 12415-12421, 1998

8. Kothari S, Cizeau J, McMillan-Ward E, Israels SJ, Bailes M, Ens K, Kirshenbaum LA and Gibson SB: BNIP3 plays a role in hypoxic cell death in human epithelial cells that is inhibited by growth factors EGF and IGF. Oncogene 22: 4734-4744, 2003.

9. Höckel M and Vaupel P: Tumor hypoxia: Definitions and current clinical, biologic, and molecular aspects. J Natl Cancer Inst 93: 266-276, 2001.

10. Vaupel P, Kelleher DK and Höckel M: Oxygen status of malignant tumors: Pathogenesis of hypoxia and significance for tumor therapy. Semin Oncol 28 (Suppl 8): 29-35, 2001.

11. Matak D, Brodaczewska KK, Lipiec M, Szymanski Ł, Szczylik C and Czarnecka AM: Colony, hanging drop, and methylcellulose three dimensional hypoxic growth optimization of renal cell carcinoma cell lines. Cytotechnology 69: 565-578, 2017.

12. Parks SK, Cormerais Y and Pouysségur J: Hypoxia and cellular metabolism in tumour pathophysiology. J Physiol 595: 2439-2450, 2017.

13. Luo L, Xiong ZB, Zeng H, Chen N, Chen XQ, Zhang P and Li X: Expression of BNIP3 and its correlations to HIF-1alpha and VEGF in clear cell renal cell carcinoma. Sichuan Da Xue Xue Bao Yi Xue Ban 43: 79-82, 2012 (In Chinese).

14. Ding Y, Yu L, Li M, Liu L and Zhong H: Establishment and biological characteristics of human renal granular cell carcinoma cell line (GRC-1). Chin J Urol 16: 3-6, 1995 (In Chinese).

15. Jiang Z, Liu X, Chang K, Liu X and Xiong J: Allyl isothiocyanate inhibits the proliferation of renal carcinoma cell line GRC-1 by inducing an imbalance between $\mathrm{Bcl} 2$ and Bax. Med Sci Monit 22: 4283-4288, 2016.

16. Sun X, Lou L, Zhong K and Wan L: MicroRNA-451 regulates chemoresistance in renal cell carcinoma by targeting ATF-2 gene. Exp Biol Med (Maywood): Jan 1, 2017 (Epub ahead of print).
17. Okami J, Simeone DM and Logsdon CD: Silencing of the hypoxia-inducible cell death protein BNIP3 in pancreatic cancer. Cancer Res 64: 5338-5346, 2004.

18. Bacon AL, Fox S, Turley H and Harris AL: Selective silencing of the hypoxia-inducible factor 1 target gene BNIP3 by histone deacetylation and methylation in colorectal cancer. Oncogene 26: 132-141, 2007.

19. Livak KJ and Schmittgen TD: Analysis of relative gene expression data using real-time quantitative PCR and the 2(-Delta Delta C(T)) Method. Methods 25: 402-408, 2001.

20. Murai M, Toyota M, Suzuki H, Satoh A, Sasaki Y, Akino K, Ueno M, Takahashi F, Kusano M, Mita H, et al: Aberrant methylation and silencing of the BNIP3 gene in colorectal and gastric cancer. Clin Cancer Res 11: 1021-1027, 2005.

21. Chinnadurai G, Vijayalingam S and Gibson SB: BNIP3 subfamily BH3-only proteins: Mitochondrial stress sensors in normal and pathological functions. Oncogene 27 (Suppl 1): S114-S127, 2008

22. Ryter SW, Mizumura K and Choi AM: The impact of autophagy on cell death modalities. Int J Cell Biol 2014: 502676, 2014.

23. Jing $\mathrm{K}$ and Lim $\mathrm{K}$ : Why is autophagy important in human diseases? Exp Mol Med 44: 69-72, 2012.

24. Gump JM and Thorburn A: Autophagy and apoptosis: What is the connection? Trends Cell Biol 21: 387-392, 2011.

25. Su M, Mei Y and Sinha S: Role of the Crosstalk between Autophagy and Apoptosis in Cancer. J Oncol 2013: 102735, 2013.

26. Mariño G, Niso-Santano M, Baehrecke EH and Kroemer G: Self-consumption: The interplay of autophagy and apoptosis. Nat Rev Mol Cell Biol 15: 81-94, 2014

27. Azad MB and Gibson SB: Role of BNIP3 in proliferation and hypoxia-induced autophagy: Implications for personalized cancer therapies. Ann N Y Acad Sci 1210: 8-16, 2010.

28. Burton TR and Gibson SB: The role of Bcl-2 family member BNIP3 in cell death and disease: NIPping at the heels of cell death. Cell Death Differ 16: 515-523, 2009.

29. Giatromanolaki A, Koukourakis MI, Gatter KC, Harris AL and Sivridis E: BNIP3 expression in endometrial cancer relates to active hypoxia inducible factor 1alpha pathway and prognosis. J Clin Pathol 61: 217-220, 2008.

30. Giatromanolaki A, Koukourakis MI, Sowter HM, Sivridis E, Gibson S, Gatter KC and Harris AL: BNIP3 expression is linked with hypoxia-regulated protein expression and with poor prognosis in non small cell lung cancer. Clin Cancer Res 10: 5566-5571, 2004.

31. Lukashova-v Zangen I, Kneitz S, Monoranu CM, Rutkowski S, Hinkes B, Vince GH, Huang B and Roggendorf W: Ependymoma gene expression profiles associated with histological subtype, proliferation, and patient survival. Acta Neuropathol 113: 325-337, 2007.

32. Erkan M, Kleeff J, Esposito I, Giese T, Ketterer K, Büchler MW, Giese NA and Friess H: Loss of BNIP3 expression is a late event in pancreatic cancer contributing to chemoresistance and worsened prognosis. Oncogene 24: 4421-4432, 2005.

33. Tang H, Liu YJ, Liu M and Li X: Establishment and gene analysis of an oxaliplatin-resistant colon cancer cell line THC8307/L-OHP. Anticancer Drugs 18: 633-639, 2007.

34. de Angelis PM, Fjell B, Kravik KL, Haug T, Tunheim SH, Reichelt W, Beigi M, Clausen OP, Galteland E and Stokke T: Molecular characterizations of derivatives of HCT116 colorectal cancer cells that are resistant to the chemotherapeutic agent 5-fluorouracil. Int J Oncol 24: 1279-1288, 2004.

35. Jacobsen J, Grankvist K, Rasmuson T, Bergh A, Landberg G and Ljungberg B: Expression of vascular endothelial growth factor protein in human renal cell carcinoma. BJU Int 93: 297-302, 2004.

36. Gardiner-Garden $\mathrm{M}$ and Frommer $\mathrm{M}$ : $\mathrm{CpG}$ islands in vertebrate genomes. J Mol Biol 196: 261-282, 1987.

37. Bird AP: CpG-rich islands and the function of DNA methylation. Nature 321: 209-213, 1986.

38. Graff JR, Herman JG, Myöhänen S, Baylin SB and Vertino PM: Mapping patterns of $\mathrm{CpG}$ island methylation in normal and neoplastic cells implicates both upstream and downstream regions in de novo methylation. J Biol Chem 272: 22322-22329, 1997.

39. Herman JG, Umar A, Polyak K, Graff JR, Ahuja N, Issa JP, Markowitz S, Willson JK, Hamilton SR, Kinzler KW, et al: Incidence and functional consequences of hMLH1 promoter hypermethylation in colorectal carcinoma. Proc Natl Acad Sci USA 95: 6870-6875, 1998. 
40. Murai M, Toyota M, Satoh A, Suzuki H, Akino K, Mita H, Sasaki Y, Ishida T, Shen L, Garcia-Manero G, et al: Aberrant DNA methylation associated with silencing BNIP3 gene expression in haematopoietic tumours. Br J Cancer 92: 1165-1172, 2005.

41. Cleven AHG, Spiertz A, Wouters B, van Engeland $M$ and De Bruine A: Stromal expression of RIF 2A correlates with BNIP3 promoter hypermethylation and overall patient survival in colorectal carcinomas. Cell Oncol 29: 127, 2007.

42. Abe T, Toyota M, Suzuki H, Murai M, Akino K, Ueno M, Nojima M, Yawata A, Miyakawa H, Suga T, et al: Upregulation of BNIP3 by 5-aza-2'-deoxycytidine sensitizes pancreatic cancer cells to hypoxia-mediated cell death. J Gastroenterol 40: 504-510, 2005.

43. Eckschlager T, Plch J, Stiborova M and Hrabeta J: Histone Deacetylase Inhibitors as Anticancer Drugs. Int J Mol Sci 18: pii: E1414, 2017.

44. Park KC, Heo JH, Jeon JY, Choi HJ, Jo AR, Kim SW, Kwon HJ, Hong SJ and Han KS: The novel histone deacetylase inhibitor, N-hydroxy-7-(2-naphthylthio) hepatonomide, exhibits potent antitumor activity due to cytochrome-c-release-mediated apoptosis in renal cell carcinoma cells. BMC Cancer 15: 19, 2015.
45. Park WH, Jung CW, Park JO, Kim K, Kim WS, Im YH, Lee MH, Kang WK and Park K: Trichostatin inhibits the growth of ACHN renal cell carcinoma cells via cell cycle arrest in association with p27, or apoptosis. Int J Oncol 22: 1129-1134, 2003.

46. Nagata $Y$ and Todokoro K: Requirement of activation of JNK and p38 for environmental stress-induced erythroid differentiation and apoptosis and of inhibition of ERK for apoptosis. Blood 94: 853-863, 1999.

47. Yang Q, Wang Y, Pan X, Ye J, Gan S, Qu F, Chen L, Chu C, Gao Y and Cui X: Frizzled 8 promotes the cell proliferation and metastasis of renal cell carcinoma. Oncotarget 8: 78989-79002, 2017.

48. Santos N, Wenger JB, Havre P, Liu Y, Dagan R, Imanirad I, Ivey AM, Zlotecki RA, Algood CB, Gilbert SM, et al: Combination therapy for renal cell cancer: What are possible options? Oncology 81: 220-229, 2011.

(c) (i) $(\Theta$ This work is licensed under a Creative Commons cc) International (CC BY-NC-ND 4.0) License. 